\title{
COGNITION AND LANGUAGE (USING THE EXAMPLE OF TRANSLATION BETWEEN RUSSIAN AND TURKISH)
}

\author{
Daria V. Zhigulskaya \\ The Institute of Asian and African Studies Moscow State University (MSU) \\ Mokhovaya str., 11/1, Moscow, Russia, 125009
}

This article discusses the relationship between cognition and language.According to the cognitive linguistics approach, the study of language is the study of language use. The languages of the world vary dramatically. They encode fundamentally different logics and structures. This paper also focuses on the phenomenon of linguistic pictures of the world, and using the Russian and Turkish languages as an example, demonstrates that absolute equivalence in translation is never possible. The results of the analysis of this issue has shown, that language does not "represent" meaning, but instead constructs meaning in particular contexts with particular cultural models and cognitive resources, while translation is the replacement of the signs encoding a message by signs from another code.

The difficulties of translating from Russian to Turkish and vice versa are primarily due to the dissimilar nature of the two languages. However, the difficulty of translation does not only exist between distinctively different languages. Surprisingly, even more complexity may sometimes arise when translating between two languages within the same family with much in common.

Thus, one may conclude that languages are structuring structures, which influence the way people think, and create linguistic habits for language users, resulting in fundamentally different ways of understanding the world.

Key words: turkology, cognition, cognitive linguistics, linguistic pictures of the world

\section{INTRODUCTION}

To begin this paper, it is necessary to focus on cognitive science and, in particular, cognitive linguistics. Cognitive science is the multidisciplinary scientific study of minds and their functioning. Despite the fact that the roots of cognitive science extend far back into intellectual history, it only emerged as a discrete scientific field in the 1950s - a time when psychology, anthropology and linguistics were redefining themselves and when computer science and neuroscience were emerging as new disciplines.

A key contributor to the emergence of cognitive science, psychologist George Miller, dates its birth to September 11, 1956, the second day of a Symposium on Information Theory at Massachusetts Institute of Technology. Computer scientists Allen Newell and Herbert Simon and linguist Noam Chomsky also took part in the symposium [1. P. 143].

The key feature of cognitive science is that it is not a discipline in its own right, but a systemic multidisciplinary scientific field. The relative prominence of the disciplines that are included in that field has varied over the years. Computer science and psychology have always played a strong role in the study of cognitive phenomena. Neuroscience 
initially was strong, but its role declined as that of linguistics increased dramatically in the 1960s. By the 1970s, such disciplines as philosophy, sociology, and anthropology were making distinctive contributions. More recently, neuroscience has once again become one of the central contributors.

As mentioned above, cognitive science is a "mixture" of different scientific disciplines, which deals with various aspects of mental processes. In practice, in order to investigate one distinct question, cognitive science has to be more limited and restrict itself to domains. One of the fields of modern cognitive science is cognitive linguistics, which focuses on the domain of language. "It deals with all questions concerning language ability, such as: What is language? How do we acquire language? What part of the brain underpins language use? Other fields of linguistic investigation center on primate language use, language acquisition, deficits in language acquisition caused by early sensory deprivation or brain damage, the relationship between language and thought, and the development of speech recognition systems" [2. P. 20].

One of the main complexities encountered in cognitive linguistics arises from the fact that language itself is very complex. In essence, it is possible to state that we know almost everything about languages but virtually nothing about language. Thus, further the main features and principal challenges of modern cognitive linguistics are discussed.

\section{DISCUSSION}

Cognitive linguistics as an approach to the study of language and human cognition had taken form by the beginning of the 1970s. The central sujbect of investigation in cognitive linguistics was the relationship between human language, the mind and sociophysical experience. In the 1970s and early 1980s a wide range of studies on this subject appeared. Among the authors who contributed most to the development of the discipline it is important to mention Len Talmy, Ronald Langacker, George Lakoff, Charles Fillmoreand Gilles Fauconnier.

According to the cognitive linguistics approach, the study of language is the study of language use. When one is engaged in any language activity one unconsciously relies on vast cognitive and cultural resources, models and frames. Thus, language does not "represent" meaning, but instead constructs meaning in particular contexts with particular cultural models and cognitive resources. Cognitive linguistics lies outside the visible boundaries of language and investigates the more complex implicit functions of cognition.

The most crucial questions to which cognitive linguistics is trying to find the answers are: Where does meaning come from? And if meaning is conceptualization, what makes concepts meaningful? George Lakoff claims that "conceptual structure is meaningful because it is embodied, that is, it arises from, and is tied to, our preconceptual bodily experience. In short, conceptual structure exists and is understood because preconceptual structures exist and are understood. Conceptual structure takes its form in part from the nature of preconceptual structures" [3. P. 265].

Due to the neuro-anatomical features of human nature, people have a species-specific view of the world. This means that perception of "reality" is mediated, in large measure, by the nature of our embodiment. The concepts we create and subsequently implement 
are a function of our embodiment. From this point of view, the human mind should bear the imprint of embodied experience.

According to the concept of linguistic pictures of the world, the real world is not represented identically in human consciousness, but is refracted and transformed by the human mind into a special world. Thus, the term linguistic picture of the world refers to the special world that is reflected in language. For this reason, the question of coherence between a national language and a national mentality is one of the central issues in cognitive linguistics: which comes first? Does national mentality form language, or does language, on the contrary, "impose" the specific features of its native speakers on national character and mentality? To some extent, this question is reminiscent of the well-known conundrum of which came first - the chicken or the egg? Yet this does not invalidate the question. Below, there is an attempt to explain the sequence of these processes.

Firstly, external conditions (such as climate and nature) together with the psychological and anthropological characteristics of a national group/society form specific features which lay down the foundations of national character and mentality. The specific features of this character and mentality are subsequently reflected and fixed in the frame of language. From this point on, these specific features are passed on to younger generations as fixed and unchangeable signs. Thus, the language in the formation phase is a product of national character and mentality, which is partly determined by external factors and environment. In later phases, changes may occur in the external environment and some factors may even disappear. Despite these changes, however, the specific features of mentality and character remain stable and continue to be passed on to each subsequent generation.

Why and how is this possible? It happens because the language "offers" new generations of its native speakers a ready-made model of national perception of the picture of the world, which is crystallized in the language. To put it more simply, the language in the formation phase is an "egg", but after its formation is completed, it becomes a "chicken".

Another crucial question concerning the concept of linguistic pictures of the world is what happens to someone who uses a foreign language not only for short-term communication (travel, business, participation in international events etc.), but who has to change his/her linguistic environment and permanently live and communicate in a foreign language sphere? This is a very complex situation, where the person finds his/ herself between two linguistic pictures of the world without belonging to either. Losing the ability to communicate in one's native language results in a dramatic reduction in one's ability to understand humor, puns, metaphors, idioms and implicit connotations (unless one is bilingual).

Living in a foreign-language environment, one is hardly able to penetrate the cognitive base of the foreign national culture, where the cognitive base is a structured range of knowledge possessed by all members of the nation. The cognitive base is always reflected in language. This is why knowledge of a foreign language at the level of language as an instrument, rather than at the level of cognitive base, inevitably leads to translation errors when a foreigner may sometimes not understand even simple phrases and words with implicit connotations that are obvious to native speakers [4].The next section of this article focuses on the problem of faithful translation and provides some examples of untranslatability, referring to the main challenges for Turkish language students. 
Modern Translation Studies distinguish three types of translation: intralingual translation (an interpretation of verbal signs by means of other signs in the same language); interlingual translation (an interpretation of verbal signs by means of some other language); intersemiotic translation (an interpretation of verbal signs by means of signs from nonverbal sign systems) [5. P. 23].

Here only interlingual translation is discussed, although the central problem in all types is that there is no full equivalence through translation. Translation is not just about transferring texts or verbal information from one language to another; it is now rightly seen as a process of negotiation between information (written or oral) and between cultures. This complicated and multi-level process, which includes different transactions, is mediated by the figure of the translator or the speaker him/herself.

The basic elements of any language are letters. "These are discrete symbols that are combined according to a set of rules. The combinations, or words, have meaning and are themselves combined according to a set of rules. The combinations, or words, have meaning and are themselves combined into other higher-order units: sentences, which also have semantic content. The rules by which these word elements are combined and transformed in language are called syntax. Syntax constitutes the set of permissible operations on the word elements. It is the elements themselves that are the mental representations" [2. P. 6]. Thus, the information must be seen as a complex system of signs and symbols and the task of the translator (or a person involved in a discussion in a foreign language) is to de-code and re-encode it.

According to the French theorist George Mounin, translation is a series of operations of which the starting point and the end product are significations and function within a given culture [6]. To clarify this statement, the subsequence of transactions in the translation process is illustrated below: source language code - analysis - code restructuring - transfer - receptor language translation.

Thus, translation is the replacement of the signs encoding a message by signs from another code, while preserving invariant information with respect to a given system of reference. Meanings vary across cultures. The meaning of a word in a language spoken by one cultural group is therefore unlikely to have an exact analogue in other languages.

Let us consider some simple examples: the Turkish expression ciğerimin köşesi, if translated into Russian without paying attention to its signification, will not be able to perform its function of meaning within the sentence, even though there may be a dictionary equivalent. While in Turkish it is used to describe someone who is very precious to you, in Russian it literally means 'a corner of my liver'.

Another example is the Russian word mujik, which translates roughly into Turkish as Russian peasant. In this case, the translation is only an adequate interpretation of an alien code unit and equivalence is impossible. Here we are faced with the phenomenon of untranslatability.

The difficulties of translating from Russian to Turkish and vice versa are primarily due to the dissimilar nature of the two languages. Turkish is an agglutinative language $-\mathrm{a}$ vital morphological characteristic that distinguishes it from the Indo-European languages and, in particular, Russian, which is an inflectional language. It would be true to say that Turkish and Russian employ fundamentally different methods of organizing and deploying speech, and of interlinking the various components of a sentence. 
For instance, thanks to the verbal-nominal form, Turkish has no need of coordinative or subordinate conjunctions, nor does it need to build dependent clauses of the IndoEuropean type. These verbal-nominal forms are initially very difficult for students of the Turkish language to grasp.

Action nouns (or masdars) and substantive-adjectival forms ( $S A F \mathrm{~S}$ ) should be classified as verbal-nominal forms.

Action nouns (masdars) are verbal forms that also have a presentive meaning, making them cognates of nouns. Thus, because these forms have certain properties that are also typical of verbs and nouns, they are known in Turkish studies as isim-fiil, or 'noun-verb' . Modern Turkish features the following action nouns: $-\boldsymbol{m a k},-\boldsymbol{m a},-(\boldsymbol{y}) \boldsymbol{\imath s}$ and the rare form -maklık.

To give an example, let us examine the phrase Bunu yapmanda fayda var, which can be translated as 'It would be useful for you to do this' or 'You ought to do this'. The masdaryapma can be literally translated as 'doing'. This form takes the second person possessive singular affix $\boldsymbol{- n}$ as well as the locative case affix -da, which literally means 'in your doing/performance'. The phrase 'fayda var' is best translated as 'there is value', giving us 'In your doing this there is value', or, in a more natural idiom, 'You ought to do this'.

The substantive-adjectival forms are able to express both "objectified" action - i.e. an action presented as an object, and "adjectivized" action. As they are also able to act as verbal substantives and verbal adjectives, they can be conveniently described as substantive-adjectival forms (SAFs) [7. Pp. 122-126].

This applies to the Turkish forms $-\boldsymbol{d} \boldsymbol{k} \boldsymbol{k},-(\boldsymbol{y}) \boldsymbol{a c a k}$ and $-(\boldsymbol{y})$ ast. One aspect of Turkish substantive-adjectival forms is the fact that, like masdars, they can take personal possessive affixes.

By way of an example, let us examine the phrases Geleceğinizi biliyordum and Geleceğiniz günü sabırsızlıkla bekliyorum. The former translates as 'I knew you (plural) would come' and is an example of the substantive use of $\boldsymbol{S A F s}$, whereas the latter can be translated as 'I look forward to the day you (plural) will come' and is an example of the adjectival use of $S A F$.

Let us look at one more example of a $\boldsymbol{S A F}$, used together with voice affixes. The phrase Ahmet, măgazadaki fiyatların sahipleri tarafından arttırıldığını söylüyor translates as 'Ahmet says that the prices in the shop have been increased by its owners'. Focusing in

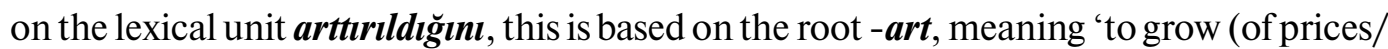
indicators), to increase'. The affix -ttr is a causative particle, indicating that the action (growth, in this case) was provoked by somebody (the shop owners, in this case). The affix $\boldsymbol{-} \boldsymbol{l} \boldsymbol{l}$ is a passive voice affix. And finally, the substantive-adjectival form - $\boldsymbol{d} \boldsymbol{\imath} \boldsymbol{k}$ indicates a substantive action. This form takes the third person singular possessive affix -I and is cognate with the word fiyatlar. Thus, fiyatların arttırıldı̆̆ can be translated as 'the fact of an increase in prices'. We then encounter a delimiting $\boldsymbol{- n}$ and the accusative affix $\boldsymbol{-} \boldsymbol{\boldsymbol { I }}$.

The difficulty of translation does not only exist between distinctively different languages (like Russian and Turkish). Surprisingly, even more complexity may sometimes arise when translating between two languages within the same family with much in common (such as Turkish and Azerbaijani). Turkish and Azerbaijani are very similar, yet there are 
still enough differences in semantics, phonology and, to some extent, grammar to make for easy misunderstandings between the two groups of speakers.

For example, the Azerbaijani sentence uçağımı on dakika sonra düssecek, meaning our plane will land in $\mathbf{1 0}$ minutes, may cause panic amongst any Turks on board, because in Turkish the verb düssecek literally means will fall. The Turks would therefore interpret the sentence as 'our plane will fall in 10 minutes'.

Consequently, to achieve equivalence in translation one should not search for sameness, since sameness cannot ever exist between two languages.

\section{CONCLUSION}

The aim of this article was to present a general concept of cognitive linguistics as a distinct discipline in the multidisciplinary field of cognitive science, using the Russian and Turkish languages as an example. The notions of linguistic pictures of the world, the cognitive base of a language and untranslatability were also introduced in this paper.

There is no doubt that language is a structuring structure and thus influences the way people think, as well as how they perceive the world, make decisions and communicate. Meanings of words are grounded in our physical and social environment. Concepts of language arise from our sensorimotor experience and the neural structures that give rise to it.

(C) Zhigulskaya D., 2017

\section{REFERENCES}

[1] Miller G.A. The Cognitive Revolution: A Historical Perspective / TRENDS in Cognitive Sciences. 2003. Vol. 7. № 3. Pp. 141-144.

[2] Friedenberg J., Silverman G. Cognitive science. An introduction to the study of mind. Sage Publications: Thousand Oaks, London, New Delhi, 2006. P. 531.

[3] Lakoff G. Women, fire and dangerous things. What categories reveal about the mind. Chicago: University of Chicago Press., 1987. P. 614.

[4] Kornilov O.A. Yazikoviye kartini mira [Linguistic pictures of the World]. Moscow: “KDU”, 2014. P. 350.

[5] Bassnett S. Translation Studies. Third Edition. Routledge: London and New York, 2002. P. 176.

[6] Mounin G. Les problmes théoriques de la traduction. Paris: Callimard, 1963. P. 290.

[7] Guzev V.G. Ocherki po teorii turkskogo slovoizmeneniya: glagol (na materiale staroanatoliyskoturkskogo yazika) [Essays on the Theory of Turkic Inflections: The Verb (Based on Material from Old Anatolian Turkic)]. Leningrad, 1990. Pp. 122-126.

For citation:

Zhigulskaya D.V. Cognition and language (using the example of translation between Russian and Turkish). RUDN Journal of Language Education and Translingual Practices, 14 (2), 253-259.

Bio Note:

Zhigulskaya Daria Vladimirovna, PhD in History, IAAS MSU. E-mail: daria.zhigulskaya@rambler. $\mathrm{ru}$ 


\title{
МЫШЛЕНИЕ И ЯЗЫК (НА ПРИМЕРЕ РУССКОГО И ТУРЕЦКОГО ЯЗЫКОВ)
}

\author{
Д.В. Жигульская \\ Институт стран Азии и Африки МГУ им. М.В. Ломоносова \\ ул. Моховая, д. 11, стр. 1, Москва, Россия, 125009
}

В статье рассматривается взаимосвязь языка и человеческого мышления. Между языками существуют кардинальные отличия, выраженные в непохожих структурах и особой языковой логике. Это приводит к отличному восприятию мира представителями разных культур и языковых традиций. В статье внимание уделяется также феномену языковых картин мира, и на примере русского и турецкого языков, демонстрируется, что абсолютная идентичность в переводе вряд ли возможна.

Языки не «отражают» значения, а, напротив, создают их в соответствии с особенными «культурными контекстами» и когнитивными ресурсами. Перевод, в свою очередь, является замещением одних знаков с «закодированными» в них значениями на знаки другого культурного кода.

Можно заключить, что язык - это структурирующая структура. Языки влияют на образ мышления людей и формируют лингвистические привычки для их носителей.

Ключевые слова: тюркология, мышление, когнитивная лингвистика, языковые картины мира

\section{Для цитирования:}

Жигульская Д.В. Мышление и язык (на примере русского и турецкого языков) // Вестник Российского университета дружбы народов. Серия: Вопросы образования: языки и специальность. 2017. T. 14. № 2. C. 253-259.

\section{Сведения об авторе:}

Жигульская Дарья Владимировна, кандидат исторических наук ИСАА МГУ. Е-mail: daria. zhigulskaya@rambler.ru 